\title{
Effects and Countermeasures of "Replacing Business Tax with VAT" to Real Estate Industry
}

\author{
Fang Zhou \\ Jinan University, Guangzhou, China \\ Email: 15011933431@163.com
}

Received 8 April 2016; accepted 15 May 2016; published 18 May 2016

Copyright (C) 2016 by author and Scientific Research Publishing Inc.

This work is licensed under the Creative Commons Attribution International License (CC BY).

http://creativecommons.org/licenses/by/4.0/

(c) (i) Open Access

\begin{abstract}
As an important measure to deepen reform of the fiscal and taxation systems, "replacing business tax with Added-Value Tax (VAT)" pilot will be carried out in all industry across our country on $1^{\text {st }}$ May 2016, the goal of the tax reformation is to have the Added-Value Tax (VAT) completely replace business tax, and to effectively avoid multiple taxation. The real estate industry, known as the foundation of national economy, will be greatly affected by the tax reformation. This paper discusses the impact of "replacing business tax with VAT" on the real estate industry's tax burden, cost, house price, profit and cash flow. Finally, some suggestions on how to deal with tax reformation for the real estate industry are put forward.
\end{abstract}

\section{Keywords}

Replacing Business Tax with VAT, Real Estate Industry, Tax Burden

\section{Introduction}

In March 2016, China formally promulgated the proposal that our country would fully implement "replacing business tax with Added-Value Tax (VAT)" pilot on 1st May 2016, which fully covers the real estate industry, construction industry, service industry and finance industry, indicating that China is devoting greater efforts to push "replacing business tax with VAT" pilot. As a highlight to deepen the reform of the fiscal and taxation systems, "replacing business tax with VAT" pilot has worked out to some extent in previous phase. After including the above four industries to the scope of pilot reformation, a fairer and more neutral tax environment will be developed in China, and it helps our country to play a more decisive role in economic activities, and it is beneficial to optimize the industrial structure. 
As the foundation of the national economy, the real estate industry is capital-intensive and labor-intensive, which also has a long production cycle. The real estate industry chain contains many links, so its development has a far-reaching influence on most of the other industries. Undoubtedly, comprehensive "replacing business tax with VAT" pilot will have significant impacts on the real estate industry; this paper aims to discuss on the influence of "replacing business tax with VAT" pilot on the real estate industry thoroughly, and put forward some suggestions on how to deal with "replacing business tax with VAT" pilot in the real estate industry.

\section{Effects of "Replacing Business Tax with VAT" on Real Estate Industry}

\subsection{Influences on Tax Burden}

The first consideration of full-round implementation of "replacing business tax with VAT" pilot reformation is that it can eliminate multiple taxation, thus reducing firms' tax burden, however, it is still unknown whether the real estate industry's tax burden is more or less after performing the "replacing business tax with VAT". The pilot reformation policy sets the added-value tax rate of real estate industry to $11 \%$, compared to $5 \%$ of the business tax rate, it seems clear that the tax rate becomes higher, however, the policy also points out that the input value-added taxes of new real estate can be fully deducted. After the "replacing business tax with VAT", the value-added tax that the real estate industry needs to pay can be calculated as the house sales (excluding taxes) multiplied by $11 \%$ and then minus the input tax (including construction and installation costs' input taxes, raw material's input taxes, land costs' input taxes, etc.). Before the "replacing business tax with VAT", the business tax that the real estate industry needs to pay is equal to the house sales multiplied by $5 \%$. If the input tax which can be deducted is more than $6 \%$ of the sales, the tax burden of real estate industry will decrease, and the tax burden will rise otherwise [1]-[4].

The input tax of construction and installation costs and costs of land account for a large amount in the input tax deductible, if these two kinds of input taxes of the real estate industry can be deducted, it is possible that firms' tax burden will decline, however, because of the long production cycle of real estate industry, in the early phase of tax reformation, real estate enterprises usually do not get the input value-added tax invoice of some construction and installation costs which occurred before the pilot. As for the cost of land, the input value-added tax is not deductible until the tax reformation is implemented. So the impact of "replacing business tax with VAT" on the real estate industry's tax burden should be inspected from a dynamic perspective, in the early phase of the pilot implementation, it is likely that the real estate industry's tax burden will rise. As time goes by, the scope of deductible input taxes will further expand, so the real estate industry's overall tax burden will decrease accordingly.

\subsection{Influences on Cost}

The cost of the real estate enterprise is mainly made up of development costs of real estate project, periodical expenses and taxes. The development cost of real estate project contains the cost of land, the engineering cost of early stage, the construction and installation cost, the indirect cost of development, the infrastructure and public facilities cost, etc. Most kinds of costs of the development cost of real estate project will not change after the "replacing business tax with VAT", however, there are some expenses which will have some effects on the cost of the real estate industry. The first kind of expense is the construction and installation cost, construction industry is also covered by the pilot, then the taxes of the construction industry will directly affect the cost of the real estate industry, if taxes of construction industry grow, for survival, they have to raise the price which directly increase the cost of the real estate industry. In addition, input taxes of construction and installation materials are included in the cost of the house before the "replacing business tax with VAT". However, after the "replacing business tax with VAT", those input taxes can be deducted. We can see that the cost of the real estate industry will slightly decline. The second kind of expense is the cost related to government charges such as the cost of land. To conclude, whether these projects' input taxes can be deduced will directly affect the cost of the real estate industry.

The periodical expense of the real estate enterprise that matters is financial expenses, given that the real estate industry is capital-intensive, real estate firms require a lot of capital investment during the construction of buildings, therefore the majority of the real estate business financial costs are relatively large. Further step of the pilot includes financial industry, as a typical modern service industry, the financial industry has a significant 
support effect for other industries, our current system of collecting business taxes on the financial sector is not good for the development of the financial sector, in order to eliminate the phenomenon of double taxation and promote the development of the financial industry, the tax reformation brings the financial industry into the "replacing business tax with VAT" pilot, thus the cost of the real estate industry will be definitely affected. Meanwhile, taxes of the real estate industry will also be influenced by the pilot, in the early phase of the pilot, taxes of the real estate industry will rise slightly, when the input taxes can be deducted, taxes might decrease, which leads the cost of real estate firms to increase slightly in the early phase and then to decrease later.

\subsection{Influences on Housing Price}

For the pilot will ultimately lead to the decline in the tax burden of real estate business, the cost of the goods are decreasing accordingly. Theoretically, as the cost of house decrease, house price will undoubtedly cool down, however, the heart of the housing price is supply and demand. On the supply side, China government puts up with the concept of "supply-side reform", which aims to encourage people to buy houses and destock housing inventory. Along with the concept, the pilot pushes the provision of new policy to support that input taxes of real estate can be deducted, which encourages real estate firms to devote more efforts to buy lands, thereby increasing the supply of houses.

In terms of the demand side, the recently-published two-child policy influences the demand for real estate to some extent, and there are more and more people to buy larger house to prepare rooms for new babies in the tier cities and second-tier cities, which promotes the transaction of the housing market. High housing price is a great pressure for most citizens to buy houses, moreover, as the implementation of the pilot, the VAT will be passed on to consumers, and so as to the value-added tax of the financial services when consumers loan to buy a house, thus it becomes more difficult for customers to afford a house after the "replacing business tax with VAT", which results in the new housing transaction will be largely affected by the pilot. For the second-hand housing transaction, the policy of the "replacing business tax with VAT" pilot take some measures to ensure the tax will decrease. According to the above theoretical analysis, the situation of oversupply in the real estate industry will last for a long time, to achieve balance between supply and demand, the house price is expected to decline, so the author deems that the house price will go down in the future.

\subsection{Influences on Profit and Cash Flow}

The profit of real estate enterprises is mainly determined by the house price and the cost. At the early stage of applying the "replacing business tax with VAT" pilot, the house price will not change obviously, but taxes of the real estate enterprise will increase, which leads the cost to rise, so the profit of the real estate industry will decline in the early phase of the pilot. As the further implementation of "replacing business tax with VAT" pilot, the taxes of real estate enterprises will reduce after wards, which helps to reduce the cost. In addition, the endeavor to balance supply and demand in the real estate market can push the house price to go down. As a result, whether the profit of the real estate industry will decrease remains unknown right now.

The booking pattern is widely used in the real estate sale. According to the regulation of the "replacing business tax with VAT", real estate enterprises should affirm income and pay taxes at the time that receives the advanced payments when selling houses, this means that real estate enterprises are required to pay a large amount of output tax before the construction of the building, whereas, the input tax which is deductible is rising slowly along with the construction. In this way, most of real estate enterprises have to pay a large sum of value-added tax at the early stage of the construction, which leads to the cash flow of the enterprise is occupied. In a long run, the overall taxes is decreasing after the whole project is completed, and the overall cash outflow of the real estate enterprise is slightly lower than before.

\section{Countermeasures for Real Estate Industry to the Tax Reformation}

The real estate industry has been to impose business tax for a long time, so the business process of the real estate enterprise is planned and designed in accordance with regulations of the business tax. After the implementation of the "replacing business tax with VAT" pilot, the business tax will not be set up in our country any more, and the VAT will realize a completely coverage of all industries, this tax reformation can not only basically eliminate the phenomenon of double taxation, but can also open up the chain of VAT deduction. As the duty of the 
business tax which is inside valence is essentially different from the value-added tax which is excluded in price, so that after the implementation of the "replacing business tax with VAT" pilot, there will be great influence on our country's economy. To better response to the tax reformation, there are some suggestions for real estate industry to take.

\subsection{Being Familiar with Tax Policy}

What the "replacing business tax with VAT" pilot brings into the real estate industry is not just the change of tax categories, and it also affects the internal control management and cost control management of enterprises, cooperation management of the industry chain and so on. Therefore, real estate enterprises should be fully familiar with the process of mastering the VAT, and attach great importance to policies of the "replacing business tax with VAT" pilot, besides, real estate enterprises should also put attention to the dynamic of the "replacing business tax with VAT", and take participate in the tax reformation proactively, and prepare as soon as possible in order to finish the "replacing business tax with VAT" pilot as early as possible. In addition, the policy that most of financial workers are familiar with in the real estate industry is the regulation of business tax, so enterprises should strengthen the tax professional knowledge for related workers, it is better to organize financial staff to learn of the new tax policies and regulations, so as to promote their awareness level of the value-added tax, to improve their business operation ability in practical work, to enhance the overall quality of the staff of enterprises, and ultimately to achieve the purpose of reducing the adverse impact on the enterprise during the two tax docking process.

\subsection{Norming Accounting Treatment}

After the "replacing business tax with VAT", real estate enterprises need to comb the input tax and the output tax rationally, and related accounting subjects should also be changed. For the input tax is included in the cost of buildings before the reformation, but after the reformation, real estate enterprises should separately ensure and measure the input tax and debit "Taxes payable-VAT-input tax" course. When selling buildings, companies do not need to credit "Taxes payable-business tax" account any more, but should confirm the output tax and credit "Taxes payable-VAT-output tax" subject. Meanwhile, the accounting treatment procedure of real estate enterprises will become more complex, companies need to set up VAT books to regulate the accounting treatment and record the situation of corporates' tax duty, so as to prevent the accounting risk in real estate enterprises, and to enhance the enterprise's internal control process.

\subsection{Optimizing Business Structure}

New real estate's input taxes can be deducted at the beginning of pushing "replacing business tax with VAT" pilot, in order to reduce the tax burden, real estate enterprises tend to increase investment in the construction of buildings, and obtain the land as soon as possible to offset the sudden increase of the output tax, so as to maintain the balance of enterprises' tax burden at the early stage of implementing the tax reformation. Certainly those measures will bring new problems, now the real estate market is highly competitive, the housing price is gradually tend to be market-oriented, and the oversupply situation is still relatively serious in real estate market now. If real estate enterprises continue to blindly increase investment, the situation of market oversupply will become increasingly serious, and may eventually hinder the development of the real estate industry. In this regard, the real estate business should optimize its business structure and investment plan reasonably, appropriate to reduce the time required during the development, and rationalize the usage of corporate funds. At the same time, according to the current trend of social development, enterprises should change the angle of analysis and investment to the differentiation and diversification of products, increase the investment in strengthening the quality of construction, and take a more diverse and flexible sales model to attract customers, so as to achieve the goal of business transformation, up gradation and optimization.

\subsection{Strengthening Invoice Management}

The VAT owns the characteristic of using invoices to control the tax, the value-added tax law in our country clearly ruled the collection, usage, management and certification of value-added tax invoices. After the implementation of "replacing business tax with VAT", real estate enterprises must focus on strengthening the man- 
agement of value-added tax invoices, and following the provisions of the tax law to use the invoice. According to the actual situation, it is better for the real estate enterprise to let someone to custody of invoices as far as possible, and try to let someone to draw up invoices at the same time, for which enterprises must strengthen the tax knowledge of relevant workers. Furthermore, as for the deductible invoice that obtaining from the procurement process, real estate enterprises should receive the invoice as soon as possible and strengthen the management of it, to ensure the timely deduction of input taxes and constantly improve the internal management of enterprises.

\subsection{Tax Planning Scientifically}

After the tax reformation, real estate industry needs to calculate output taxes according to the sales, and also needs to pay attention to getting input tax invoices. In order to scientifically plan for the payment of tax, enterprises should take the following advices into consideration. First, when selecting the material supplier, real estate enterprises shouldn't give up to obtain the input tax invoice for some small concessions, enterprises must take it as an important premise whether the supplier can issue VAT invoices when choosing the supplier. Second, it is better to get the special invoices for value-added tax at the first time. Third, in the construction process, real estate enterprises must strictly control the use of the sporadic employment, because sporadic labors often cannot offer the special invoices for value-added tax. Last but not least, in addition to the large-scale pre-sale mode, the enterprise should also adopt diversified sales model on the basis of the actual situation, to extend the time of sales revenue recognition of the company as longer as possible.

\subsection{Taking Multi-Stakeholders into Consideration}

Real estate industry chain is longer, so the development of the real estate industry has significant promotion function for many industries. Its upstream link is material such as steel, cement and so on, the development and construction of projects need the help of construction and installation industry, its downstream demand is terminal customer, and the development of the entire real estate industry chain needs the help from the financial sector. After fully implementing the pilot, the input tax from material purchasing, financing, constructing and installing can all be deducted, this suggests that the interests of the real estate industry and many other industries are interconnected. Therefore, real estate enterprises should focus on in-depth communication with the relevant industry, take care of the interests of both parties in the process of operation, so as to realize the win-win complexion of the partner involved in the industrial chain.

\section{Conclusion}

The tax reformation of "replacing business tax with VAT" pilot will cause a huge influence on the development of real estate industry. The tax burden, the cost, the housing price, the profit and the cash flow of real estate enterprises will change a lot after the implementation of the pilot. So real estate enterprises must take measures actively to deal with the tax reformation, and catch the dividend policy from the government to reform the operation mode and reshape organization structure, thus achieving the goal of better development of real estate industry.

\section{References}

[1] Gao, P.Y. (2013) On Replacing Business Tax with VAT: Purpose, Function and Practice. Taxation Research, 7, 3-9.

[2] Pan, W.X. (2013) On the Phenomenon of Burden Increase in Some Service Industry Enterprises during Substituting the Value-Added Tax for Business Tax Reform. Journal of Guangdong University of Business Studies, 1, 43-49.

[3] Tian, Z.W. and Hu, Y.J. (2013) Dynamic Analysis of Effects of Industry Tax Burden on the Transformation from Business Tax to VAT-Based on CGE Model. Collected Essays on Finance and Economics, 7, 29-34.

[4] Peng, X.J., et al. (2015) Effect Evaluation of Replacing Business Tax with VAT in Real Estate Industry. Taxation Research, 11, 37-41. 